\title{
Research on Using Seaweeds as Biofuel by Using Vacuum Drying Method
}

\author{
Chen Cheng and Shuichi Torii \\ Department of Advanced Mechanical Systems, Kumamoto University, Kumamoto 860-8555, Japan
}

Received: May 12, 2013 / Accepted: June 03, 2013 / Published: December 25, 2013.

\begin{abstract}
Seaweeds carry out photosynthesis to convert inorganic carbon into organic substances, such as hydrocarbons or neutral lipids. And those resulting products can be used as biofuel. The $\mathrm{CO}_{2}$ fixation ability of seaweeds is much greater than other plants on earth, but directly extracting lipids from seaweeds is quite inconvenient and extravagant. In this study, Vacuum drying method to dry seaweeds to biofuel directly was used which can save cost and energy compared with extract process. It has been tested at $60{ }^{\circ} \mathrm{C}$, $70{ }^{\circ} \mathrm{C}$ and $80^{\circ} \mathrm{C}$, respectively under normal atmospheric pressure. The experimental results show that vacuum drying method can save cost and energy observably and the shortest time is also the lowest power cost.
\end{abstract}

Key words: Seaweeds, biofuel, vacuum drying, $\mathrm{CO}_{2}$ fixation.

\section{Introduction}

In recent decades, with the increasing energy demand, the problem of climate change and greenhouse emission from traditional fossil fuels becomes more and more serious, while now renewable energy as a clean energy sources is still the minority of the current total primary energy production. Biomass as one of renewable energy is not only produced from plants, animals, and micro-organisms but also from organic wastes. They usually absorb the $\mathrm{CO}_{2}$ by photosynthesis or metabolism, so biomass as a new energy source could decrease the $\mathrm{CO}_{2}$ emission amount greatly. Biomass may become a source of local energy, and microalgae seem to be promising because of their high photosynthetic efficiency, high biomass production, and fast growth [1]. The idea of converting algae to biofuels was first suggested in 1955 [2], and has been pursued more intensely in recent decades [3-7]. As a matter of fact, average biodiesel production yield from microalgae can be 10 to 20 times higher than the yield obtained from oleaginous seeds and/or vegetable oils [8,

Corresponding author: Chen Cheng, research field: new energy. E-mail: Chencheng0122@hotmail.com.
9] (Table 1). Some microalgae have high oil content (Table 2) and can be induced to produce higher concentration of lipids (e.g., low nitrogen media, $\mathrm{Fe}^{3+}$ concentration and light intensity) [10-14].

However, the most biological producer of oil from microalgae is difficult or impossibleused immediately. And also, extract process is complicated and with high cost. In this study, we used low cost process-vacuum drying method, to decrease the biomass cost and make biofuel to be used directly. We also focus on the lowest power cost during the vacuum drying method and calorific value under different moisture content of biomass.

\section{Materials and Methods}

\subsection{Sample Preparation}

Compare with the other microalgae, Chlorella vulgarishas higher reproductive capacity and cultural method is simpler. However, until the experiment stated, Chlorella vulgaris haven't enough quantity to support. We chose Ceratophyllumdemersum to replace it and began the experiment. Each time $2 \mathrm{~g}$ simple is dispersedly put in the bottom of jar, and fixed 
Table 1 Comparison of some sources of biodiesel.

\begin{tabular}{ll}
\hline Crop & Oil yield (L/ha) \\
\hline Corn & 172 \\
Soybean & 446 \\
Canola & 1,190 \\
Jatropha & 1,892 \\
Coconut & 2,689 \\
Oil palm & 5,950 \\
Microalgae $^{\text {a }}$ & 136,900 \\
Microalgae $^{\text {b }}$ & 58,700 \\
\hline
\end{tabular}

a $70 \%$ oil (by wt) in biomass.

b $30 \%$ oil (by wt) in biomass.

Table 2 Lipid content of some microalgae (\% dry matter).

\begin{tabular}{ll}
\hline Species & Lipids \\
\hline Scenedesmus obliquus & $11-22 / 35-55$ \\
Scenedesmus dimorphus & $6-7 / 16-40$ \\
Chlorella vulgaris & $14-40 / 56$ \\
Chlorella emersonii & 63 \\
Chlorella protothecoides & $23 / 55$ \\
Chlorella sorokiana & 22 \\
Chlorella minutissima & 57 \\
Dunaliella bioculata & 8 \\
Dunaliella salina & $14-20$ \\
Neochloris oleoabundans & $35-65$ \\
Spirulina maxima & $4-9$ \\
\hline
\end{tabular}

into the water bath. Every time preheat the water bath to target temperature. (Fig. 1).

\subsection{Drying and Temperature}

Before the experiment started, we test the moisture content of original simple every time (90 $\pm 1 \%)$. The purpose of final moisture content is average 30\%. So we tested under $60{ }^{\circ} \mathrm{C}, 70^{\circ} \mathrm{C}$ and $80^{\circ} \mathrm{C}$, respectively, and each temperature condition cost $20 \mathrm{~min}, 30 \mathrm{~min}$, and 40mins respectively. Under these factors, each of the experiment test has been done at least 10times.

\subsection{Analytical Method}

In the experiment, we used vacuum pump (N810FT.18, Knf, Japan), weight measurement by electron steelyard (AF-R220, Vibar, Japan), moisture content measurement used electrical moisture meter (MOC63u, Shimadsu, Japan), calorific value measurement used calorimeter (CA-4AJ, Shimadsu, Japan), and power cost measurement used eco keeper (EC-03EB, Elpa, Japan).

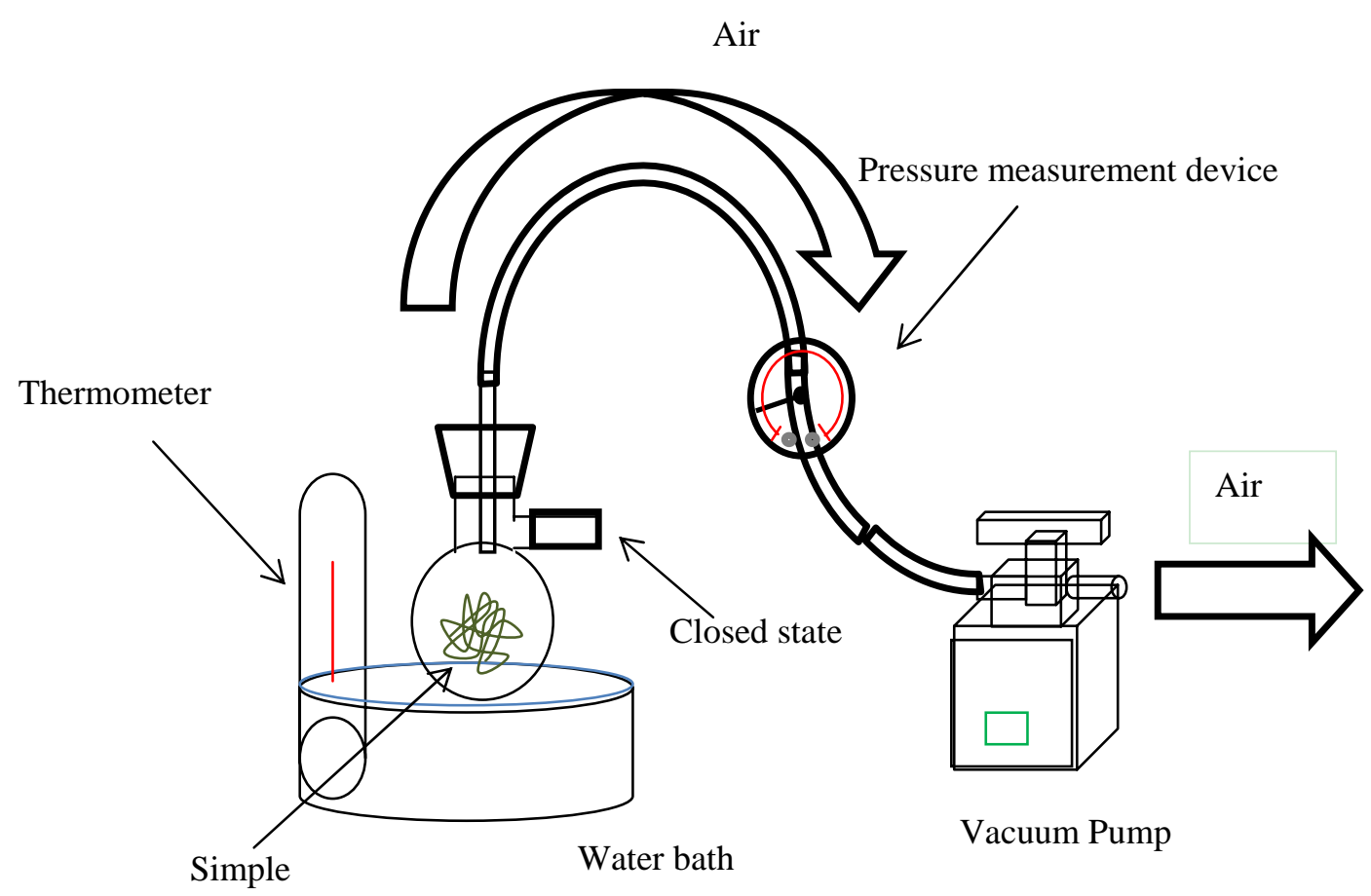

Fig. 1 Experimental apparatus. 


\section{Results and Discussion}

Because of vacuum pump's high power, after 5-10mins, the vacuum degree in the jar reaches to $0.080 \mathrm{MPa}$, and become steadily. According to the standard atmospheric pressure (0.101 $\mathrm{MPa})$, the pressure in the bottle is almost $0.020 \mathrm{MPa}$, under this condition, the boiling point of water is nearly $60{ }^{\circ} \mathrm{C}$, which is the same as the starting temperature of the experiment.

According to Fig. 2, moisture content decreased with the drying time increased obviously. But under different temperature condition, the moisture content
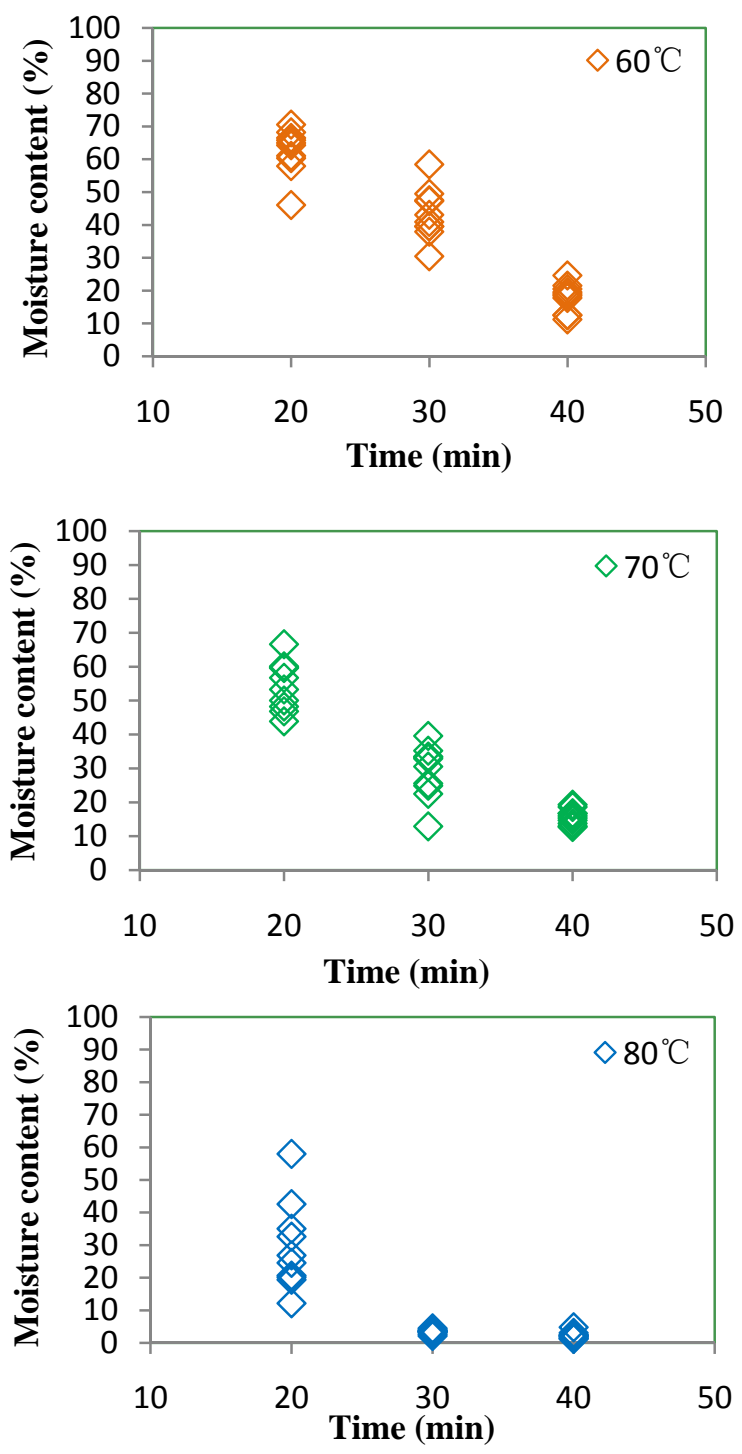

Fig. 2 The relation of time and moisture content on $60^{\circ} \mathrm{C}$, $70{ }^{\circ} \mathrm{C}, 80^{\circ} \mathrm{C}$. is quite different. At $60{ }^{\circ} \mathrm{C}$, after $40 \mathrm{mins}$ moisture content just under $30 \%$, at $70{ }^{\circ} \mathrm{C}$, after $30 \mathrm{mins}$, moisture content average in $30 \%$, and at $80{ }^{\circ} \mathrm{C}$ condition, after 20 min even moisture content was not stable enough, but it was still under 30\% (Fig. 3). All the date conform the moisture content under $30 \%$ become stably, and decreased with moisture content, thestable of the date increased.

Basically, calorific value was increased with moisture content decreased (Fig. 4), and of course high calorific value means more value in the practical application. But the more moisture content decreased, means the more energy cost we need in biomass production. According to Fig. 5, obviously energy cost was increased with temperature increasing, which because high water temperature needs more energy cost. Under the condition of $60^{\circ} \mathrm{C}, 70^{\circ} \mathrm{C}$ and $80^{\circ} \mathrm{C}$, heating the water $\left(20^{\circ} \mathrm{C}\right)$ to the specified temperature cost 50.4 , 102.4 and $168 \mathrm{~kJ}$, respectively. Obviously, the higher of preheating temperatureis, the greater of energy consumption it cost. But in order to practical application, we should consider about quantity and continuity test. Under condition of moisture content $30 \%, 60^{\circ} \mathrm{C}, 70^{\circ} \mathrm{C}$, $80{ }^{\circ} \mathrm{C}$ cost $40 \mathrm{~min}, 30 \mathrm{~min}$ and $20 \mathrm{~min}$ respectively. And during these 20-40 min, they had cost average 48.4, $54.4,36 \mathrm{~kJ}$ to keep the temperature at $60{ }^{\circ} \mathrm{C}, 70{ }^{\circ} \mathrm{C}$ and

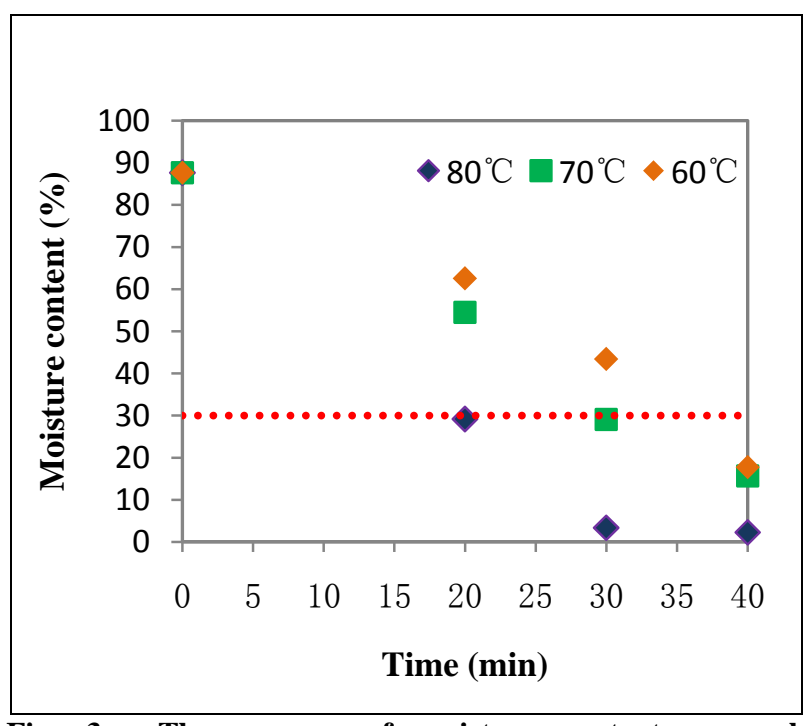

Fig. 3 The average of moisture content on each temperature. 


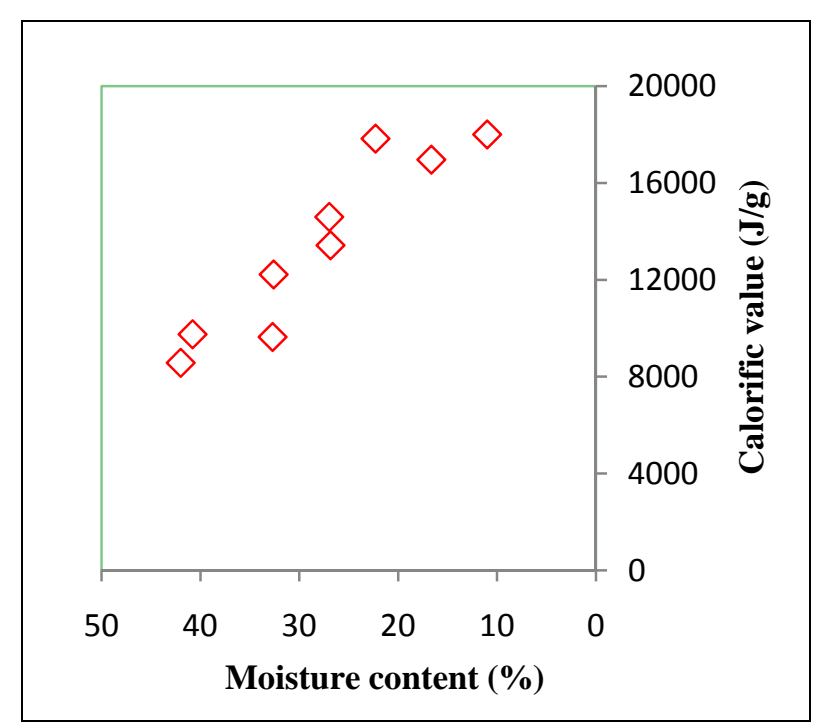

Fig. 4 The relation between moisture content and calorific value.

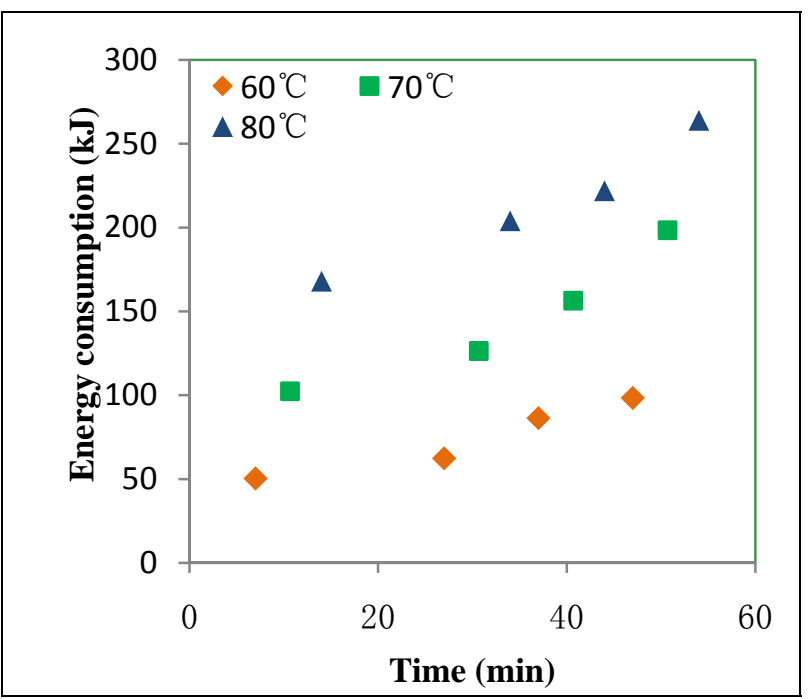

Fig. 5 The relation between time and energy consumption.

$80{ }^{\circ} \mathrm{C}$, respectively. That means, without preheat energy cost, the shortest time $\left(80^{\circ} \mathrm{C}, 20 \mathrm{~min}\right)$ spend the fewest power.

\section{Conclusions}

A vacuum method has been successfully applied to biofuel produce experiment at $60{ }^{\circ} \mathrm{C}, 70{ }^{\circ} \mathrm{C}, 80^{\circ} \mathrm{C}$ respectively. According to the low pressure condition, seaweeds have been easily drying. Under different condition, energy cost increased with temperature increasing and time consumption. At $60{ }^{\circ} \mathrm{C}$ condition total power cost is the lowest, and at $80{ }^{\circ} \mathrm{C}$ is the highest power cost. But without preheat energy spending, the shortest time, $20 \mathrm{~min}$ at $80^{\circ} \mathrm{C}$ spend the fewest power.

\section{References}

[1] M. Calvin, S.E. Taylor, Fuel from algae, Algal and Cyanobacterial Biotechnology, Longman Scientific and Technical Wiley, New York, 1989, pp. 136-160.

[2] R.L. Meier, Biological Cycles in the Transformation of Solar Energy into Useful Fuels, Wisconsin: Solar Energy Research, Madison University Wisconsin Press, 1955, pp. 179-183.

[3] X.L. Miao, Q.Y. Wu, C.Y. Yang, Fast pyrolysis of microalgae to producerenewable fuels, Journal of Analytical and Applied Pyrolysis 71 (2) (2004) 855-863.

[4] T. Minowa, S. Yokoyama, M. Kishimoto, Oil production from algal cells of dunaliella tertiolecta by direct thermochemical liquefaction, Fuel 74 (12) (1995) 1735-1738.

[5] S. Sawayama, T. Minowa, S.Y. Yokoyama, Possibility of renewablenergy production and $\mathrm{CO}_{2}$ mitigation by thermochemical liquefaction of microalgae, Biomass \& Bioenergy 17 (1) (1999)33-39.

[6] T.A. Milne, R.J. Evans, N. Nagle, Catalytic conversion of microalgae and vegetable oils to premium gasoline, with shape-selective zeolites, Biomass \& Bioenergy 21 (3) (1990) 219-232.

[7] Y.F. Yang, C.P. Feng, Y. Inamori, T. Maekawa, Analysis of energy conversion characteristics in liquefaction of algae, Resources Conservation and Recycling 43 (1) (2004) 21-33.

[8] Y. Chisti, Biodiesel from microalgae, Biotechnol. Adv. 25 (2007) 294-306.

[9] J. Tickell, From the Fryer to the Fuel Tank, The Complete Guide to Using Vegetable Oil as an Alternative Fuel, Tallahasseee, USA, 2000,

[10] A.M. llman, A.H. Scragg, S.W. Shales, Increase in Chlorella strains caloriWc values when grown in low nitrogen medium, Enzyme. Microb. Technol. 27 (2000) 631-635.

[11] Z.Y. Liu, G.C. Wang, B.C. Zhou, Evect of iron growth and lipid accumulation in Chlorella vulgaris, Bioresour Technol 99 (2007) 4717-4722.

[12] W.L. Rodol, N. Bassi, G. Padovani, G. Bonini, G.C. Zitelli, N. Biondi, et al., Lipid production from microalgae: Strain selection, induction of lipid synthesis and outdoor cultivation in pilot photobioreactors, in: Proceedings of the 15th European conference and exhibition, Berlin, 2007, pp. 100-112.

[13] A.E. Solovchenco, I. Khozin-Goldberg, S. Didi-Cohen, Z. 
Cohen, M.N. Merzlyak, Evects of light intensity and nitrogen starvation on growth, total fatty acids and arachidonic acid in the green microalga Parietochloris incise, J. Appl. Phycol. 20 (2008) 245-251.
[14] T.G. Tornabene, G. Holzer, S. Lien, N. Burris, Lipid composition of the nitrogen starved green alga Neochlorisoleabundans, Enzyme. Microb. Technol. 5 (1983) 435-440. 